\title{
Transmigrant Farmers Adaptation to Rainfed Rice Field and Irrigated Rice Field in North Luwu Regency, South Sulawesi - Indonesia
}

\author{
Eliza Meiyani ${ }^{1}$ \\ ${ }^{1}$ Muhammadiyah University of Makassar, Indonesia \\ Correspondence: Eliza Meiyani, Muhammadiyah University of Makassar, Indonesia. E-mail: \\ eliza_meiyani@yahoo.co.id
}

Received: December 9, 2014

Accepted: February 14, 2015

Online Published: October 31, 2015

doi:10.5539/mas.v9n12p243

URL: http://dx.doi.org/10.5539/mas.v9n12p243

\begin{abstract}
This research is aimed to study the anthropology of transmigration, particularly on transmigrants' adaptation to different cultural background and environment of their new place. There are three analyzed variables in this research: the farmers' basic ability, culture (tradition), and motivation which might closely related to their adaptation capability in a new location. This is a quantitative research and it was conducted in Malangke District, North Luwu Regency, South Sulawesi. Multi-stage cluster random sampling was used as the sampling method. There were 400 samples taken in this study which consist of 200 farmers of rainfed ricefield and 200 farmers of irrigated rice field. The data was taken by conducting several interviews which are based on a question list and observation. Then the data was analyzed using factor (main component) analysis, path analysis, and product-moment correlation analysis. The result shows that transmigrants' adaptation capability is not influenced only by the new physical environment condition where they live, but also their origin as well as the social, economic, and cultural factors that become parts of their life.
\end{abstract}

Keywords: transmigrant, rainfed rice field, irrigated rice field, motivation, culture

\section{Introduction}

Farming is one of main livelihoods of Indonesian people until now. It is still a main people's employment regardless of ecosystem changes to urban and industrial areas. Therefore, agriculture development will be necessary for the next several years. facilitat

Development in industrial sector, alongside with agricultural development, also grows rapidly. This situation leads to some unwanted effects; one of them is reduction of farming land in Java Island at the rate of 23,000 hectares/year. Meanwhile, Java provides 30 million tons of rice per year, that is $62 \%$ of national rice demand. Due to this conversion, it is estimated that rice production decreases 25-27 thousand tons per year (BPS data, 2013). One of the alternative methods to compensate this loss is extensification by forming tidal rice field outside Java, such as Sumatera, Kalimantan, Sulawesi, and Irian Jaya. It is similar to Syahza's opinion (2007) that in order to realize the objective of people's economy development, particularly in agricultural sector, the government needs to formulate a strategic policy to increase the agricultural development in terms of people's income and prosperity.

The policy of Provincial Government of South Sulawesi to optimize land use is implemented in two ways: by developing tidal land into irrigated land and by sponsoring transmigrants to come from Java. They started to arrive since 1970. There were 920 families (4,994 people) arrived at some tidal lands during 1970-1975, for instance in Malangke District of Luwu Regency.

Rice production reached 2.0 - 3.0 tons/hectare during the first five years of their residence in the tidal and irrigated rice field, and rice was grown by all transmigrants. Consequently, both Javanese transmigrants and local people were highly dependent on agricultural product, particularly rice, during the first five years.

After the first five-years term, unexpectedly they suffered a very real economic problem, especially the decline of rice production, and this failure had been predicted. It was caused by unstable condition of the rainfed rice field, the handling method, as well as the soil's chemical and biological condition changes.

Considering this loss, some of the Javanese transmigrants moved to other area for better prosperity. Abdoellah (1990) showed that the number of Javanese transmigrants that left Malangke rice field reached almost $49 \%$ of 
the transmigrant families sent by the government. On the other hand, some transmigrants who stayed in the area tried to do anything possible to survive in an unpredicted environment.

There are many researches on rice field of Malangke District of North Luwu Regency, but those studies are focused in specific field of study, such as agrophysics and biology. In contrast, anthropological studies on transmigration are rarely conducted, particulary on the transmigrant adaptation in a new location. One of the studies is a study that was conducted by Abdoellah (1990) on transmigrant adaptation strategy of different cultural backgrounds. While this study is focused on sociology and anthropology, but it is emphasized in adaptation capability comparison of transmigrant farmers in South Sulawesi.

It is aimed to describe adaptation capability of transmigrant farmers who has different culture (Javanese and Sundanese), live in transmigrant area of South Sulawesi, and have the same economic and ecological problems. Basically, social group and community institution of those cultural groups are forms of community structure and their dynamics depends on the people's behavior pattern in dealing with a particular situation (Poerwanto, 1999). It is supported by Dharmawan (2007) who said that transmigrant's survival capacity or success in sustaining their life and build their livelihood system depend on many factors, such as: social infrastructure, structure, and superstructure.

Adaptation is one of basic concepts in ecological anthropology. Alland (1975) defined adaptation as a human strategy to anticipate physical and social environmental changes. Similarly, Abdoellah (1990) stated that someone's adaptability influences his/her life and the higher their adaptability, the higher their chance of survival. In other words, adaptation is a dynamic process where an individual tries to maximise her/his chance of living due to the constantly changing environment and human population.

All the theories mentioned above remind us that human and environment are the ecosystem's dynamic parts, and they are occured in both modern and traditional communities. They also realize that functional and mutual relationship between social and biophysics unites both of them in an ecosystem.

Sahlin (1968), similar to the other's opinion, stated that adaptation is a process where an individual maximizes their chance of living. Meanwhile, Bennet (1966) stated that adaptation is a mutual process between people and physical environment, in which an individual attempts to adjust their behavior to match with any physical environmental challenges.

This point of view has been used for a long time by Steward and it is called cultural ecology. In 1995, he explained that there si a mutual relationship between physical and cultural environments. Steward's basic theory is then followed up by Geertz study on Javanese people. Geertz's theory (1976) confirmed that community's adaptation characteristics depend on their effort or intelligence in contending mother nature.

It is possible that this adaptation process described by Steward happens in any community structures. According to this theory, general problems found in rainfed rice field and irrigated rice field can be solved as long as the obstacles are eliminated. The farmers should be able to work harder, energetically, and know their area well using their intellegence to struggle against any environmental difficulties. On the other hand, culture is simply a drift factor of the changes. Therefore, the researcher is focused in analyzing the farmers' tradition, motivation, intention, and basic capacity (since they are parts of their culture) to know whether or not those factors influence transmigrants' adaptation process in South Sulawesi transmigrant area.

According to Garna (1996), the tradition is integrated in people's life. It is difficult to omit it and it tends to be developed using cultural elements of other communities. Similar to the traditional factors, motivation is also an important factor that helps farmers to adapt to their environment. A higly motivated person has higher enthusiasm and considerable strength. This is the fundamental purpose of motivation. In such a way, it is easy to predict that highly motivated farmers will be able to adapt more easily.

Farmer's basic capacity consists of education, training, experience, and capital resources. According to some experts, educated, well-trained, and experienced farmers who have adequate capital resources are able to develop their farming to a profitable, productive, and sustainable business.

Based on the theories, there are three research hypothesis which need to be proved: (1) tradition, motivation, intention, and basic capacity variables that influence the Javanese and Sundanese transmigrant farmers' adaptation capability in the ricefield area; (2) difference between Javanese and Sundanese transmigrant are influential to their adaptation capability; (3) difference in adaptation capability between Javanese and Sundanese transmigrants will influence their social and economic level. 


\section{Research Method}

This is a quantitative research and, therefore, the researcher needs to operationalize indicator-based variables. The variable's indicators show many appropriate data or information, so that the hypothesis test model can be made using more precise statistical method.

Based on the theories and hypotheses mentioned in the previous chapter, the researcher used the following research variables: (1) farmers' adaptation capability, (2) tradition, (3) motivation, (4) initiative, (5) basic capacity, and (6) social and economic level.

In order to find a research area, the researcher selected some villages which has some potential in both rainfed and irrigated rice fields, and are occupied by transmigrant farmers of the same ethnic group. Based on this criteria and field observation, this research was conducted in Malangke District, North Luwu Regency, South Sulawesi Province.

The researcher used multi-stage cluster random sampling as the sampling method. A random and simple selection of each rainfed rice field population is the first stage of this research, and it generates six locations.

Second stage, the researcher randomly selected some families of each six locations. The numbers of selected families is determined proportionally. Observation units of this research are the head of family household and the analysis units are farmer families (Creswel, 2009).

To decide the number of selected families (sample size), the researcher used Cohen's sample size formulation that suggests the researcher to use more than 200 samples in a factor analysis. There were 400 samples taken in this study which consist of 200 farmers of rainfed ricefield and 200 farmers of irrigated rice field. The data was taken by conducting several interviews which are based on a question list and observation. Finally, the hypotheses were analyzed by means of factor (main component) analysis, path analysis, and product moment correlation analysis.

\section{Findings and Discussion}

Some transmigrants who stayed in the rainfed and irrigated rice field areas tried to identify any efforts that may help them to survive in an unpredicted environment. There is, of course, a binding factor of why they stayed in the area while the other transmigrants moved to other places with the intention of finding a better life. According to Iskandar (2002), successful farming is closely related to the farmer's productivity itself. His study is narrowed down to the following points: 1) Farmers' work ethic is positively correlated to their productivity. The better their work ethic, the higher their productivity, and vice versa. Work ethic variable is must be considered seriously to improve farmer's productivity in cultivating their land; 2) Their motivation for success is positively correlated to their productivity. The stronger their motivation, the higher their working productivity, and vice versa. Therefore, their motivation is an important variable and researchers must pay a close attention to it in order to improve their productivity; 3) Farmers' innovation is also positively correlated to their productivity because the more positive their innovation, the higher their productivity in cultivating the land, and vice versa. That is why, in order to improve their productivity in cultivating their farming land, the farmers should positively innovative in adopting new farming technology that suits their surrounding ecological condition; 4) Of those independent variables, each of them is positively correlated to working productivity and they are significantly influential to the farmers' productivity in cultivating their land.

Elizabeth (2007) defines farmers' community as a traditional community. This context should not be perceived only as hired labour who has an 'exchange rate' and 'added value', but should be perceived also as a people who are able to educate themself (or to develop human rights). Their economic system is called as "family farming system". Farmers' community is a dynamic and heterogenous group of people since there are rich, average, and poor farmers. According to her, there are four main properties of farmer community: (1) Farmer family is the basic unit of a double-dimensions society, (2) farmers get their income from farming business by cultivating their land; (3) their culture pattern is traditional and distinctive; and (4) farmers are in lower social level than people who live in higher level of community.

However, the result of this study describes only the variables that have been set in the hypotheses and it is assumed that those variables are closely relatted to the farmers' adaptation process. This process is aslo influenced by social values they have set among them. Hartati (2008) explains that value of togetherness, cooperation, and trust are truly and positively influential to adaptation process.

Based on a regression procedure test, it is known that motivation variable showed insignificant result ( $\mathrm{p}$-value $=$ 0.59). However, the other variables, such as farmers' tradition, initiative, and basic capacity contribute to the adaptation at the rate of $54.9 \%$ which consists of $43.11 \%$ for tradition, $5.4 \%$ for initiative, and $9.55 \%$ for basic 
capacity.

The motivation variable is not significant probably because the transmigrant farmers were trying to obey government's policy due to the lack of business opportunities in their hometown. They did not fully understand the objective of transmigration, that is to be a successful farmer, and use this objective as a motivation to work harder.

Meanwhile, test result of farmers who live in irrigated rice field showed that farmer's tradition and basic capacity were insignificant and initiative variable of farmers who live in rainfed rice field also less significant to the farmers' adaptation capability. Another report explains that economic exploitation by the colonial government in the past that caused famine due to government policy (Ibrahim, 2004).

Despite of some pattern differences in both areas, the condition of irrigated rice field motivates the farmers to improve their adaptability. It makes sense because water supply in irrigated rice field can be managed by means of social adjustment and technical engineering.

The researcher also found that the number of farmers that overcome the difficulty is increasing, while the numbers of farmers that give in to the difficulty are decreasing. It implicitly indicates that farming in irrigated rice field is easier because of water availability. One of these research findings is a fact that farmers of irrigated rice fields are able to optimize their land better than farmers of the rainfed rice fields. For example, some irrigated rice field can be cultivated twice a year. This research finding is similar to the researches of Sinulingga (2000) and Choliq (1993) in terms of irrigated rice field percentage that can be cultivated twice a year. This convenience factor allows farmers to discover the right and more productive farming methods. As a result, the number of farmers that overcome the difficulty is increasing, while the numbers of farmers that give in to the difficulty are decreasing.

It is roughly estimated that farmers' adaptability pattern tends to differ between the two ethnic groups of this study. $14.6 \%$ of Javanese farmers' adaptability is low, $69.6 \%$ is average, and the remaining $17.9 \%$ of them is high. On the other hand, $10.4 \%$ of Sundanese farmers' adaptability is low, $89.6 \%$ of them is high, and no one reach a high level.

Based on this description, there is a factual adaptability difference, in which Javanese farmers adaptability is higher than Sundanese farmers. Javanese farmers are, in general, easy to feel comfortable in a new place. This comfortable feeling is a sign of their adaptability in a new place. Therefore, it is concluded that Javanese farmers, besides having a long history of migration to other places, they also have a more mature motivation, cultural call, and personal readiness when they leave their hometown than other transmigrants. As a comparison, a study on Javanese transmigrants' motivation has been conducted by Hartati (2008) in North Luwu Regency. This study found that: (1) Percentage of Javanese and Balinese migration motivation is $72.11 \%$ and it is categorized as highly motivated; and (2) afiliation, achievement, and power variables are significantly influential to Javanese transmigrants motivation.

In contrast, Sundanese culture does not have strong value of migration. This opinion is commonly related to Sundanese proverb "stay together in ups and downs". Sundanese people can be considered as sedentary community. It is a community that closely related to their birth place, and this relationship makes Sundanese people do not interested in leaving their birth place unless they are forced to leave. In short, adaptation is a difficult process for Sundanese people because it is not easy for them to feel at home.

Another similar study was conducted by Purhantara (2010) on the existence of migrant Madurese people in Sleman. Madurese people have a strong willingness and this character was formed by the harsh natural environment of Madura. They use this characteristic in Sleman as a capital to start a business. Their characteristics of hard working, risk taking, creating product/service innovation, attention to find new opportunities, and spirit of competition make them recognized by people of Sleman. Their ability to start a business and to create business/good/service innovations reflects business people behavior to win a competition in the same field.

Back to this study, the t-test shows that farmers' adaptation influences their social and economic improvement. It means that there is a tendency of the higher the farmers' adaptability, the higher the social and economic status they achieve. The strong relationship between adaptability and economic status scores 0.214 . In other words, $4.75 \%$ of their social and economic status improvement is influenced by their adaptability.

In the rainfed rice field, the strong relationship between adaptability and social economic status scores 0.916 . It means that their adaptability contribute $3.84 \%$ to their social and economic status improvement. Meanwhile, the relationship in irrigated rice field community scores 0.315 , which means that $9.92 \%$ of the farmers' social and 
economic status is influenced by their adaptability.

In experts' perspective, adaptability is important for people's welfare. According to Abdoellah (1990), Adimiharja (1993), and Soemarwoto (1997), the higher their adaptability, the higher their chance to survive. Similar to the other's opinion, stated that adaptation is a process where an individual maximizes their chance of living (1968).

Tulak (2009) also stated the same thing, that socio-cultural characters of transmigrants' family are highly influential to their economic welfare level. This statement refers to his study on social economic research in Manokwari. Javanese farmers' family has a much higher income than Papuanese farmers' family because of their perception in responding economic challenges in the area. In this context, the presence of non-farming sectors is strongly influential to social and economic transformation in the study area. Although non-farming sector encourages the economy and contributes to people's saving capacity, it also causes some negative impacts such as striking difference in social and economic welfare disparity.

This description shows that adaptability is significantly contribute to the farmers' social and economic status improvement. Those who are highly adaptive will achieve higher social and economic level. Therefore, adaptation should be holistically translated in terms of ecological anthropology framework. By using this approach, it is important to identify a complex interaction between physical and cultural environments. This interaction will determine transmigrants' adaptability to a new culture in rainfed and irrigated rice field areas of South Sulawesi.

\section{Conclusion}

This study finds that transmigrants' adaptability is not influenced only by physical environment condition, but also by various cultural conditions. Some cultural varibles that influence their adaptability are their tradition, initiative, and basic capability. In contrast, motivation variable does not show a significant result.

Cultural variable in rainfed rice field environment and irrigated rice field environment also show a different pattern in influencing transmigrant farmers' adaptability. In rainfed rice field, initiative variable is less important in improving transmigrant farmers' adaptability.

Farmers' ethnical origin is not significantly influence their adaptability in rainfed and irrigated rice fields. It shows that Javanese and Sundanese ethnicities are similarly potential to adapt to a new environmental condition.

Meanwhile, there is an adaptability difference between transmigrant farmers of rainfed and irrigated rice fields. Transmigrant farmers of irrigated rice field have a better adaptability. It is positively influential to their social status improvement. In irrigated rice fields, correlation and contribution of farmers' adaptability to social and economic status improvement are higher than the correlation and contribution in tidal rice fields.

Based on those findings, the researcher suggests three points: First, it is necessary to improve the implementation of feasibility study results on each appointed transmigration area. Second, it is important to develop farming technology, land use arrangement, water management, and other supporting infrastructures that suitable for irrigated farming lands. Third, knowledge selection and transfer for future transmigrants need to be adjusted to the field conditions they are going to experience. At last, cultural and physical environment condition of the transmigrants' origin should be put into consideration in preparing their transmigration areas.

\section{References}

Abdoellah, O. S. (1990). Indonesian Transmigrant and Adaption: A. Ecological Antropological Perspective. Berkeley: University of California Dissertation.

Abdoellah, O. S. (1996). Social and environmental impacts of transmigration: a case study in Barambai, South Kalimantan. In Padoch, C., \& Peluso, N. L. (Eds.), Borneo in transition: People, Forests, conservation, and development (pp. 266-279). Oxford University Press, London.

Abdoellah, O. S., Hadikusumah, H., Takeuchi, K., Okubo, S., \& Parikesit. (2006). Commercialization of homegardens in an Indonesian village: vegetation composition and functional changes. In B.M. Kumar, \& P.K.R. Nair (Eds.), Tropical Homegardens: A Time-Tested Example of Sustainable Agroforestry. Springer, The Netherlands.

Adimihardja, K. (1993). Culture and Environment.. Bandung: Ilham Jaya.

Alland, Jr. A. (1975). Adaption. Annual Review of Antropology.

Bennet, J. W. (1996). Human Ecology as Human Beahvior. London: Transaction Publishers.

Choliq, A. (1993). Against Contributions Irrigation Impact Factor of Production and Income Distribution in Irrigation Area Farmers, Cihaur Sidareja Kabupaten Cilacap Jawa Tengah. Bandung: Disertasi UNPAD. 
Creswell J. (2009). Research Design: Qualitative, Quantitative, and Mixed Methods Approaches. 3rd Edition. Los Angeles: Sage Publications, Inc.

Dharmawan, A. H. (2007). System Livelihoods and Rural Livelihoods: The views Sociology Livelihoods (Livelihood Sociology) schools of West and schools of Bogor. sodality: Jurnal Transdisiplin Sosiologi, Komunikasi dan Ekologi Manusia, 01(02).

Elizabeth, R. (2007). Farmers Metamorphosis Sociological Phenomenon: Towards Alignments the Community Farmer On The Marginalized Rural Concepts Related to Economic Democracy. Agro Economic Research Forum, 25(1). 29-42.

Garna, (1996). Indonesian Culture System. Bandung: Graduate Program UNPAD.

Geertz, C. (1976). From the native's point of view: On the nature of anthropological understanding. In K. Basso, \& H. Selby (Eds.), Meaning in anthropology (pp. 221-237). Albuqeurque: University of New Mexico Press.

Hartati, P. (2008a). Motivation Migration In General Transmigration Transmigration Settlement Unit Pongkase In Luwu Utara. Journal of Agrisistem, 4(1), 30-45.

Hartati, P. (2008b). Community Adaptation Migrants In Social Environment. Journal of Agrisistem, 4(2), 75-90.

Ibrahim. J. (2004), Economic exploitation of Japanese Occupation in Surakarta (1942-1945). Humaniora, 16(1), $35-49$.

Iskandar, O. (2002). Work ethic, motivation, and attitude on Productivity Innovative Farmers. Makara. Sosial Humaniora, 6(1).

Luthfi, A. (2010). Access and Control of Women Farmers Cultivators On Agricultural Land PTPN. Jurnal Komunitas, 2(2), 9-19

Poerwanto, H. (1999). Assimilation, acculturation and National Integrasi. Humaniora, 11(3), 29-37.

Purhantoro, W. (2010). Business Conduct at Madura Society Overseas In Sleman. Jurnal Solusi, 5(2).

Sahlins, M. D. (1968). Culture and Environment. In Sol Tax (Ed.), Chicago: Horizons of Antropology.

Steward, J. H. (1995). Theory of Culture Change. Urbana: University of Illions Press.

Syahza, A dan Khaswarina, S. (2007). Oil Palm Plantation Development and Welfare Farmer on Riau. Jurnal Sorot, 1(2), 45-65.

Tulak, P. P. dkk. (2009). Farmer Household Livelihoods structure Migrants: Socio-Economic Study In Three Village In the district of Manokwari District Masni. Sodality: Jurnal Transdisiplin Sosiologi, Komunikasi dan Ekologi Manusia, 3(2), 60-75.

\section{Copyrights}

Copyright for this article is retained by the author(s), with first publication rights granted to the journal.

This is an open-access article distributed under the terms and conditions of the Creative Commons Attribution license (http://creativecommons.org/licenses/by/3.0/). 